\title{
PENINGKATAN PEMAHAMAN PENYAKIT COVID19 PADA JAMAAH MASJID DARUL FALAH, CEPER, KLATEN
}

\section{The Increased understanding of the disease Covid-19 in the community of the Darul Falah mosque, Ceper, Klaten}

\section{Em Sutrisna}

Fakultas Kedokteran, Universitas Muhammadiyah Surakarta Korespondensi: Em Sutrisna. Alamat email: em.sutrisna@ums.ac.id

\begin{abstract}
ABSTRAK
Penyakit Corona/ Covid-19 telah mewabah di Indonesia. Penyakit ini menyebar diseluruh wilayah Indonesia baik perkotaan maupun pedesaan. Informasi yang banyak dan berasal dari media sosial sangat mempengaruhi pemahaman masyarakat. Informasi yang salah akan berakibat pemahaman yang salah. Pengabdian ini ditujukan untuk meningkatkan pemahaman warga jamaah masjid Darul Falah, Ceper Klaten tentang penyakit Covid-19. Metode pelaksanaan dengan ceramah penyuluhan. Sesekali audien ditanya untuk mengetahui pemahaman mereka tentang penyakit Corona. Hasil penyuluhan menunjukkan bahwa penyuluhan meningkatkan pemahaman peserta terhadap penyakitCovid-19. Kesimpulan dari pengabdian ini adalah bahwa penyuluhan akan meningkatkan pemahaman jamaah masjid tentang penyakit Covid-19.
\end{abstract}

Kata Kunci: Covid-19, penyuluhan, pemahaman

\section{ABSTRACT}

Corona / Covid-19 disease has become epidemic in Indonesia. This disease spreads throughout the country. A large amount of information that comes from social media greatly affects people's understanding. The wrong information may lead to people's wrong understanding. This community service was aimed at increasing the understanding of the community of Darul Falah mosque about Covid-19. The method for implementation of this community service was by extension lectures. Occasionally the audiences were asked to find out their understanding of Corona disease. The results showed that the health counseling increased participants' understanding of Covid-19. This service concluded that counseling will increase the understanding of mosque congregations about the Covid-19 disease.

Keywords: Covid-19, health counseling, people understanding. 


\section{PENDAHULUAN}

Pada Desember 2019, dilaporkan adanya pasien yang dirawat dengan ARDS di Wuhan China. Kasus tersebut meningkat pesat sampai awal tahun 2020. Setelah dilakukan penelitian ternyata penyebab dari penyakit tersebut adalah varian baru Corona virus yang kemudian diberi nama SARS Cov-2 (Ren et al, 2020). Pada 11 Februari WHO memberikan nama penyakit sebagai Covid-19 (Corona virus disease) yang disebabkan oleh virus SARS Cov-2 (WHO, 2020a). Sejak saat ini Covid-19 terus menyebar ke seluruh dunia.

Di Indonesia, kasus Covid-19 pertama kali dilaporkan pada tanggal 2 maret 2020 sebanyak 2 kasus (WHO, 2020b). Jumlah ini terus meningkat seiring berjalannya waktu sampai sekarang. Data menunjukkan pada tgl 17

Desember 2020, kasus korona di dunia 74.672.924 dengan jumlah kematian 1.658.268. Kasus di Indonesia pada tanggal 18 Des terdapat 643.508 kasus dengan 7.354 kematian (Worldometer, 2020).

Sumber informasi tentang Covid-19 yang sampai ke masyarakat beragam. Validitas sumber informasi juga beragam. Maka pemahaman masyarakat terhadap penyakit juga berbeda-beda yang dipengaruhi tingkat pendidikan maupun sumber informasi yang didapat. Penyuluhan ini dilakukan untuk meningkatkan pemahaman masyarakat terhadap penyakit Covid-19 ini. Penyuluhan ini diharapkan dapat menimbulkan pemahaman yang benar tentang penyakit Covid-19 dan merubah perilaku yang pada akhirnya akan menghambat/mengurangi transmisi penyakit ini.

\section{TUJUAN DAN MANFAAT}

Tujuan dari pengabdian ini adalah meningkatkan pemahaman masyarakat sasaran terhadap penyakit Covid-19, sehingga diharapkan akan meningkatkan kesadaran dan perilaku yang benar terhadap penyakid Covid-19 ini. Tujuan akhirnya akan mengurangi risiko terpapar atau memamapar terhadap masyarakat lain.

\section{METODE PELAKSANAAN}

Metode pelaksanaan kegiatan Pengabdian masyarakat inui adalah dengan penyuluhan interaktif tentang penyakit Covid-19. Sesekali peserta penyuluhan ditanya tentang pemahaman terhadap penyakit Covid-19 ini. Analisis pemahaman peserta dilakukan secara kualitatif oleh persepsi pemateri. 
Desain pelaksanaan digambarkan sebagai berikut:

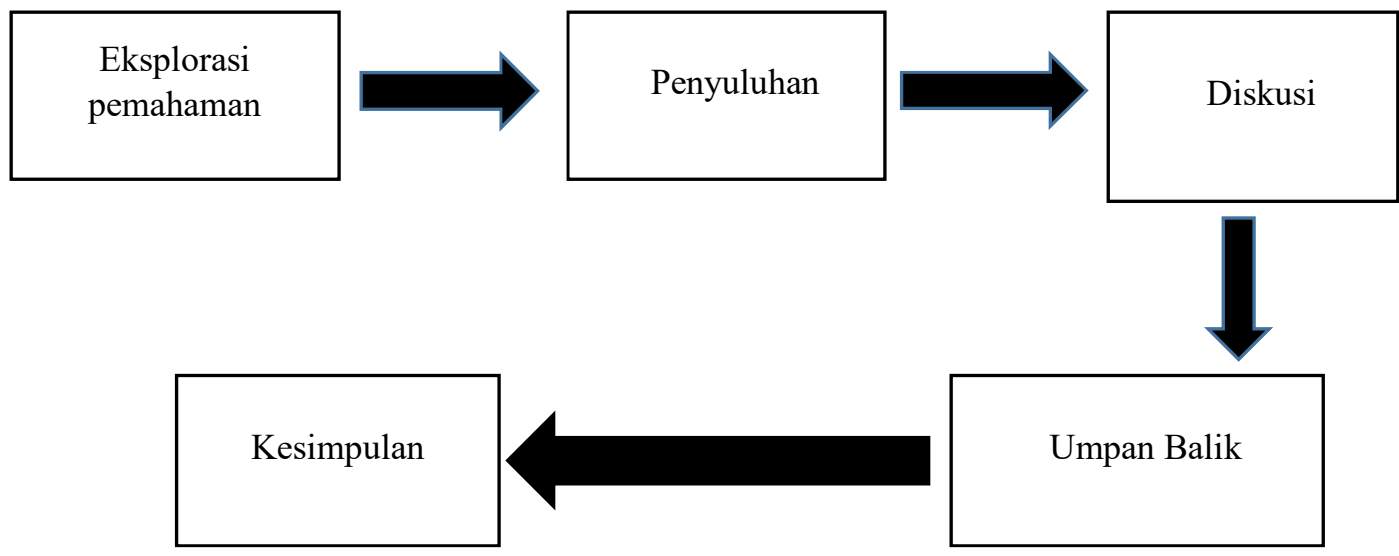

\section{HASIL DAN DISKUSI}

Masyarakat sasaran dari penyuluhan ini adalah jamaah masjid Darul Falah, Klaten. Sebanyak sekitar 12 orang mengikuti kegiatan ini baik laki-laki maupun perempuan. Pada tahap awal nampak bahwa pemahaman peserta tentang penyakit ini sangat dangkal dan beragam bahkan sebagian ada pemahaman yang salah. Ketika ditanya maka didapat bahwa sumber informasi tersebut dari media sosial. Pada tahap awal pertemuan, peserta ditanya tentang sumber informasi tentang Covid-19 dan pemahaman mereka terhadap penyakit Covid-19 ini.

Dari pertanyaan tersebut didapatkan data sebagai berikut:

a. Sumber informasi Covid-19 bagi peserta berasal dari televisi, media sosial (face book, wa dan alin-lain), internet, informasi langsung dari masyarakat yang menyebar. b. Pemahaman yang sudah mereka dapatkan dengan benar adalah mengenai penyebab penyakit adalah virus dan penyakit Covid19 bisa menular.

c. Pemahaman yang salah dari sebagain peserta adalah mengenai gejala penyakit yang menurut peserta penyuluhan harus ada batuk dan pilek. Mereka merasa aman cukup dengan masker.

d. Hal umum yang belum mereka fahami adalah tentang mengapa harus menggunakan masker berlapis, bagaimana konsep isolasi, mengapa gejalanya bermacam macam dan mengapa bisa muncul gangguan pembauan

Di akhir penyuluhan peserta ditanya secara cuplik untuk mengetahui pemahaman 
Covid-19 pasca penyuluhan dan komitmen mereka untuk mencegah penularan Covid-19 ini.

\section{SIMPULAN DAN SARAN}

Penyuluhan secara efektif meningkatkan pemahaman peserta. Diharapkan selanjutnya kegiatan penyuluhan dilakukan secara berkesinambungan dan bisa direcord untuk diupload di media sosial sehingga lebih banyak masyarakat yang akan mengaksesnya.

\section{DAFTAR PUSTAKA}

Ren L-L, Wang Y-M, Wu Z-Q, Xiang Z-C, Guo $\mathrm{L}, \mathrm{Xu} \mathrm{T}, 2020$. Identification of a novel coronavirus causing severe pneumonia in human: a descriptive study. Chin Med J.; published online February 11.
Worldometer, 2020. Covid-19 Coronavirus Pandemic. Available from: (https://www.worldometers.info/corona virus/?utm campaign=homeAdUOA?Si

WHO, 2020a. Naming the coronavirus disease (COVID-19) and the virus that causes it. [Internet]. Available from: https://www.who.int/emergencies/diseas es/novel-coronavirus-2019/technicalguidance/naming-the-coronavirusdisease-(covid-2019)-and-the-virus-thatcauses-it

WHO, 2020b. Coronavirus disease 2019 (COVID-19) Situation Report - 42. [Internet]. [updated 2020 March 02; cited 2020 March 15]. Available from: https://www.who.int/docs/defaultsource/coronaviruse/situationreports/20200302-sitrep-42-covid19.pdf?sfvrsn $=224 \mathrm{c} 1$ add 